\title{
The role of ice in $\mathrm{N}_{2} \mathrm{O}_{5}$ heterogeneous hydrolysis at high latitudes
}

\author{
R. L. Apodaca, D. M. Huff, and W. R. Simpson \\ Department of Chemistry and Biochemistry and Geophysical Institute, University of Alaska Fairbanks, Fairbanks, Alaska, \\ 99775-6160, USA
}

Received: 27 May 2008 - Published in Atmos. Chem. Phys. Discuss.: 2 July 2008

Revised: 21 November 2008 - Accepted: 25 November 2008 - Published: 15 December 2008

\begin{abstract}
We report evidence for ice catalyzing $\mathrm{N}_{2} \mathrm{O}_{5}$ heterogeneous hydrolysis from a study conducted near Fairbanks, Alaska in November 2007. Mixing ratios of $\mathrm{N}_{2} \mathrm{O}_{5}$, $\mathrm{NO}, \mathrm{NO}_{2}$, and ozone are reported and are used to determine steady state $\mathrm{N}_{2} \mathrm{O}_{5}$ lifetimes. When air masses are subsaturated with respect to ice, the data show longer lifetimes $(\approx 20 \mathrm{~min})$ and elevated $\mathrm{N}_{2} \mathrm{O}_{5}$ levels, while ice-saturated air masses show shorter lifetimes $(\approx 6 \mathrm{~min})$ and suppressed $\mathrm{N}_{2} \mathrm{O}_{5}$ levels. We also report estimates of aerosol surface area densities that are on the order of $50 \mu \mathrm{m}^{2} / \mathrm{cm}^{3}$, a surface area density that is insufficient to explain the rapid losses of $\mathrm{N}_{2} \mathrm{O}_{5}$ observed in this study, reinforcing the importance of other reactive surfaces such as ice. Consideration of two possible responsible types of ice surfaces, the snowpack and suspended ice particles, indicates that both are reasonable as possible sinks for $\mathrm{N}_{2} \mathrm{O}_{5}$. Because ice-saturated conditions are ubiquitous in high latitudes, ice surfaces are likely to be a key loss of $\mathrm{N}_{2} \mathrm{O}_{5}$, leading to nitric acid production and loss of $\mathrm{NO}_{\mathrm{x}}$ in high latitude plumes.
\end{abstract}

\section{Introduction}

Tropospheric pollutants such as ozone and nitric acid $\left(\mathrm{HNO}_{3}\right)$ are of growing concern due to their environmental impacts and associated health concerns. Nitrogen oxides, particularly the rapidly cycling family referred to as $\mathrm{NO}_{\mathrm{x}}$ (=nitric oxide, $\mathrm{NO}+$ nitrogen dioxide, $\mathrm{NO}_{2}$ ), play a critical role in the production of ozone and $\mathrm{HNO}_{3}$ in the troposphere. During the day, $\mathrm{NO}_{\mathrm{x}}$ enters catalytic cycles that produce ozone, and in some locations the amount of ozone produced is considered hazardous to human health (Finlayson-Pitts and Pitts, 2000). $\mathrm{NO}_{\mathrm{x}}$ can also destroy ozone at night (Brown

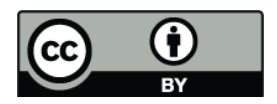

Correspondence to: W. R. Simpson (ffwrs@uaf.edu) et al., 2006a). From an atmospheric chemistry viewpoint, ozone is also important in that it controls many aspects of atmospheric oxidation processes. The ultimate fate of $\mathrm{NO}_{\mathrm{x}}$ is to be oxidized to nitric acid and subsequently deposited to the surface of Earth. $\mathrm{NO}_{\mathrm{x}}$ oxidation and removal limits the extent to which catalytic production of ozone occurs. Furthermore, deposition of $\mathrm{HNO}_{3}$ generated by $\mathrm{NO}_{\mathrm{x}}$ oxidation results in acid deposition and nitrogen fertilization, potentially altering soil and surface water nutrients and $\mathrm{pH}$ and causing changes in biota in sensitive ecosystems (Fenn et al., 2003; Bergholm et al., 2003; Allan et al., 1999; Heintz et al., 1996; Andersen and Hovmand, 1995).

Atmospheric $\mathrm{NO}_{\mathrm{x}}$ removal chemistry is diurnal in nature, with different processes occurring during day and night. Daytime $\mathrm{NO}_{\mathrm{x}}$ removal is driven by the presence of the hydroxyl radical $(\mathrm{OH})$ in the following reaction,

$\mathrm{NO}_{2}+\mathrm{OH}+\mathrm{M} \rightarrow \mathrm{HNO}_{3}+\mathrm{M}$.

Nighttime removal of $\mathrm{NO}_{\mathrm{x}}$ proceeds through the formation of the oxidative intermediates nitrate radical $\left(\mathrm{NO}_{3}\right)$ and dinitrogen pentoxide $\left(\mathrm{N}_{2} \mathrm{O}_{5}\right)$ in what is termed the "dark" oxidation pathway.

$$
\begin{aligned}
& \mathrm{NO}_{2}+\mathrm{O}_{3} \rightarrow \mathrm{NO}_{3}+\mathrm{O}_{2} \\
& \mathrm{NO}_{2}+\mathrm{NO}_{3}+\mathrm{M} \rightarrow \mathrm{N}_{2} \mathrm{O}_{5}+\mathrm{M} \\
& \mathrm{N}_{2} \mathrm{O}_{5}+\mathrm{M} \rightarrow \mathrm{NO}_{3}+\mathrm{NO}_{2}+\mathrm{M} \\
& \mathrm{N}_{2} \mathrm{O}_{5}+\mathrm{H}_{2} \mathrm{O} \stackrel{\text { surface }}{\rightarrow} 2 \mathrm{HNO}_{3} .
\end{aligned}
$$

In the following sections of this manuscript $k_{i}$ refers to the rate coefficient for Reaction ( $\mathrm{Ri}$ ).

In recent years, multiple optical techniques to detect $\mathrm{NO}_{3}$ and $\mathrm{N}_{2} \mathrm{O}_{5}$ have been developed to study this pathway (Platt et al., 1980; Geyer and Stutz, 2004; Stutz et al., 2004; King et al., 2000; Brown et al., 2001, 2002, 2003; Simpson, 2003; Wood et al., 2003; Ayers et al., 2005; Brown et al., 2006b;

Published by Copernicus Publications on behalf of the European Geosciences Union. 


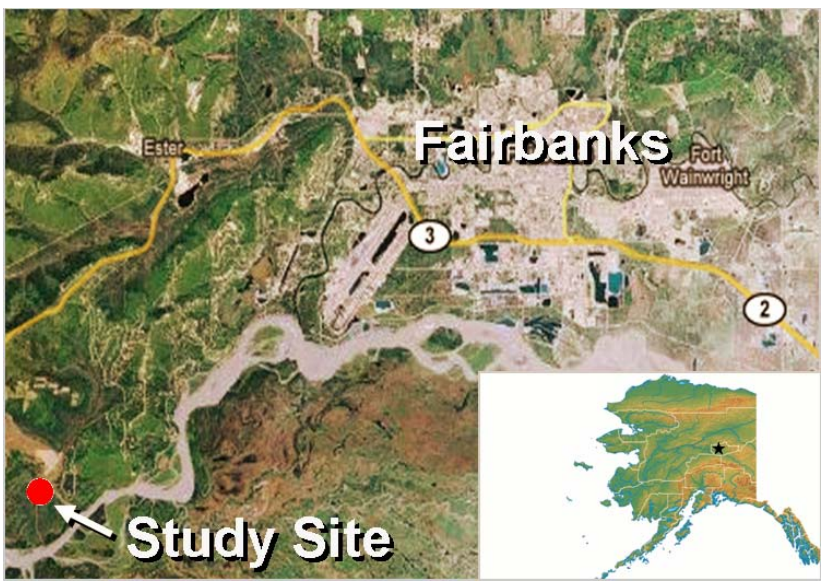

Fig. 1. A satellite image showing the study site location and its relationship to Fairbanks and the surrounding area. The map inset shows the location of Fairbanks in interior Alaska.

Nakayama et al., 2008). In a number of studies, these techniques have been used to determine $\mathrm{NO}_{3}$ and $\mathrm{N}_{2} \mathrm{O}_{5}$ lifetimes, and one study has demonstrated the direct determination of the reactive uptake coefficient of $\mathrm{N}_{2} \mathrm{O}_{5}, \gamma\left(\mathrm{N}_{2} \mathrm{O}_{5}\right)$, on ambient aerosol particles (Brown et al., 2006b).

The landmark modeling study by Dentener and Crutzen (1993) suggests that the dark loss mechanism is the main loss process of nitrogen oxides at high latitudes in winter. Factors that contribute to the prominence of the dark oxidation pathway at high latitudes are outlined below. Long nights allow $\mathrm{NO}_{3}$ to form without photolysis acting as a major sink. Short days and low sunlight intensity result in low $\mathrm{OH}$ radical abundance that reduces the importance of the daytime $\mathrm{NO}_{\mathrm{x}}$ oxidation pathway. Reactions (R2) and (R3) are half reactions of a temperature dependent equilibrium between $\mathrm{NO}_{3}$ and $\mathrm{N}_{2} \mathrm{O}_{5}$. Thermal dissociation of $\mathrm{N}_{2} \mathrm{O}_{5}$ (Reaction R3) results in similar abundances of $\mathrm{NO}_{3}$ and $\mathrm{N}_{2} \mathrm{O}_{5}$ under warm conditions. However, under cold conditions, such as at high latitudes, the dissociation rate of $\mathrm{N}_{2} \mathrm{O}_{5}$ slows, resulting in increased partitioning towards $\mathrm{N}_{2} \mathrm{O}_{5}$. For example, at $25^{\circ} \mathrm{C}$ and $5 \mathrm{ppbv}$ (parts per billion by volume) $\mathrm{NO}_{2}$, the equilibrium ratio $\left[\mathrm{N}_{2} \mathrm{O}_{5}\right] /\left[\mathrm{NO}_{3}\right]$ is equal to 4 . Under cold conditions $\left(-20^{\circ} \mathrm{C}\right)$ and 5 ppbv $\mathrm{NO}_{2}$, the equilibrium ratio $\left[\mathrm{N}_{2} \mathrm{O}_{5}\right] /\left[\mathrm{NO}_{3}\right]$ is equal to 3190 . If heterogeneous hydrolysis rates are slow, $\mathrm{N}_{2} \mathrm{O}_{5}$ could potentially be transported long distances in cold air masses such as those found at higher latitudes or high altitudes.

A factor that may moderate dark oxidation of $\mathrm{NO}_{\mathrm{x}}$ is the fast reaction of $\mathrm{NO}$ with $\mathrm{NO}_{3}$, which acts as a sink of $\mathrm{NO}_{3}$,

$\mathrm{NO}_{3}+\mathrm{NO} \rightarrow 2 \mathrm{NO}_{2}$.

Nitric oxide may be present either from direct emissions, which can persist at night in ozone-titrated air masses, or from photolysis of $\mathrm{NO}_{2}$ in the day. Away from direct emissions (i.e. outside of a city) and under nighttime conditions, the NO sink is often small.

Ayers and Simpson (2006) have demonstrated that high latitude $\mathrm{N}_{2} \mathrm{O}_{5}$ lifetimes are significantly shorter than ones reported at lower latitudes. To characterize $\mathrm{N}_{2} \mathrm{O}_{5}$ removal mechanisms at high latitudes, we measured $\mathrm{N}_{2} \mathrm{O}_{5}$ using offaxis cavity ring-down spectroscopy (oa-CRDS) (Ayers et al., 2005). With these data and measurements of aerosol particles and ice saturation conditions, we demonstrate that ice is largely responsible for catalyzing $\mathrm{N}_{2} \mathrm{O}_{5}$ heterogeneous hydrolysis at high latitudes.

\section{Measurements}

In-situ $\mathrm{N}_{2} \mathrm{O}_{5}$ mixing ratios were measured using an off-axis cavity ring-down spectroscopy field instrument described in Apodaca (2008), and based on the optical technique developed by Ayers et al. (2005). The instrument's precision and accuracy have been verified in an intercomparision exercise carried out at the SAPHIR reaction chamber in Jülich, Germany, as described in Apodaca et al. (2008). Briefly, ambient air is continuously pulled through a sampling cell at 8 standard liters per minute. A Teflon filter $(47 \mathrm{~mm}$ Pall Teflo membrane, $2.0 \mu \mathrm{m}$ pore size) is housed at the mouth of the inlet to minimize light extinction by particles in the cavity. Based on recommendations in Apodaca et al. (2008), the filters were changed every 3 to $4 \mathrm{~h}$ to prevent sample loss due to contaminated filters. It was standard practice to examine the data pre- and post-filter change, looking for improved transmission of $\mathrm{N}_{2} \mathrm{O}_{5}$ following a filter change. If an aerosol-loaded filter was producing significant sample loss, we would expect to see higher $\mathrm{N}_{2} \mathrm{O}_{5}$ mixing ratios following filter changes as compared to just prior to changing a filter. We did not observe increases in $\mathrm{N}_{2} \mathrm{O}_{5}$ upon insertion of clean filters every 3 to $4 \mathrm{~h}$. The all-Teflon analysis cell is heated to measure the sum of $\mathrm{NO}_{3}+\mathrm{N}_{2} \mathrm{O}_{5}$. The sample first passes through a stage where it is heated to $100^{\circ} \mathrm{C}$, rapidly dissociating the $\mathrm{N}_{2} \mathrm{O}_{5}$ to $\mathrm{NO}_{3}+\mathrm{NO}_{2}$ (Reaction $\mathrm{R} 3$ ). The sample then enters the second stage where it is probed by measuring direct absorption of $\mathrm{NO}_{3}$ at $662 \mathrm{~nm}$ via off-axis cavity ringdown spectroscopy. The sample is maintained at $85^{\circ} \mathrm{C}$ in the second stage to prevent repartitioning back to $\mathrm{N}_{2} \mathrm{O}_{5}$.

The measurements were made at a remote field site located about $20 \mathrm{~km}$ WSW of downtown Fairbanks, Alaska (Fig. 1). Fairbanks and the surrounding area have a population of approximately 80000 people, making it the second largest population center in Alaska. Fairbanks is geographically isolated, particularly from other anthropogenic $\mathrm{NO}_{\mathrm{x}}$ sources, with the nearest major city more than $400 \mathrm{~km}$ to the south and separated by the Alaska Range with typical elevations ranging from $2000 \mathrm{~m}$ to $3000 \mathrm{~m}$. The study site $\left(64.75^{\circ} \mathrm{N}, 148.09^{\circ} \mathrm{W} ; 135 \mathrm{~m}\right.$ elevation) was located in a 45 -acre agricultural field, cleared of trees and covered by 
seasonal snowpack throughout the study. To the north lie the hills of the Tanana uplands with peak elevations of about $1000 \mathrm{~m}$. To the south lie the Tanana River and expansive Tanana flats with an elevation of about $130 \mathrm{~m}$. Radiative cooling resulted in cold temperatures during the study period with strong temperature inversions and highly stratified air. The predominant winds during this study were from the NNE, resulting in the site being at least $20 \mathrm{~km}$ downwind from the nearest large $\mathrm{NO}_{\mathrm{x}}$ source, the city of Fairbanks. To the best of our knowledge, the biogenic $\mathrm{NO}_{\mathrm{x}}$ contribution has not been characterized in the Fairbanks region. Furthermore, little is known about NO emissions from soils at low temperatures, and even less is known about NO emissions from snow-covered soils. A study by Koponen et al. (2006) indicates that biogenic NO soil emissions are suppressed at low temperatures. For example, Koponen et al. (2006) report that when the soil temperature is near $-5^{\circ} \mathrm{C}$, the soil NO flux is $\approx 1.5$ micrograms $\mathrm{N} / \mathrm{m}^{2} / \mathrm{hr}$. That NO will mix through the snow and into the boundary layer, being oxidized by $\mathrm{O}_{3}$ as it mixes upwards. Simple box model estimates, using a surface layer of $1 \mathrm{~m}$ and a lifetime for the oxidation of $\mathrm{NO}$ by $\mathrm{O}_{3}$ of 4 min, predict the steady state biogenic NO mixing ratio to be approximately $0.15 \mathrm{ppbv}$. This level of NO is below the detection limits of the $\mathrm{NO}_{\mathrm{x}}$ analyzer used in this study (see below). Oxidation and slow transport of the NO through the snowpack would probably hold the NO significantly lower than this value in the actual case. Once the NO is oxidized, it will add $\mathrm{NO}_{2}$ to the boundary layer and is likely to mix over a higher height. Assuming a height of $10 \mathrm{~m}$ and a $4 \mathrm{~h}$ timescale for the boundary layer to ventilate, we get about 1 ppbv $\mathrm{NO}_{2}$ in the boundary layer. While this level might contribute to the $\mathrm{NO}_{\mathrm{x}}$ budget, it is significantly lower than anthropogenic $\mathrm{NO}_{\mathrm{x}}$ from Fairbanks. Therefore, the nitrogen oxides measured in this study are generated in the Fairbanks area without significant contribution from other regional sources. Strong temperature inversions coupled with the topography and weak winds made the study site ideal for observing the isolated Fairbanks pollution plume after significant transport and aging time.

The study was conducted continuously from 7 November 2007 through 19 November 2007. The oa-CRDS instrument was mounted outdoors and the inlet was maintained at $1 \mathrm{~m}$ above the snowpack surface. Ancillary measurements of $\mathrm{NO}$ and $\mathrm{NO}_{2}$ were collected using a Thermo Environmental $42 \mathrm{c} \mathrm{NO}_{\mathrm{x}}$ analyzer. Ozone measurements were collected using a Dasibi 1008 RS instrument. Aerosol particle number density was measured with a condensation particle counter (TSI CPC 3010) that had a lower size cutoff of approximately $10 \mathrm{~nm}$. A 3-stage modified DRUM impactor and ion chromatography analysis were used to measure the size distribution and determine the chemical composition of aerosol particles (Perry et al., 1999; Cahill, 2003). The DRUM impactor was operated in a mode where aerosol particles were impacted on a spot on a Teflon strip. After two hours of sample acquisition, an automated stepping motor moved the impaction location to a separate spot. The spots were visible on the strip due to black carbon present in the aerosol, and were cut out and eluted in ultrapure water and analyzed by ion chromatography (Dionex ICS-2000). Wind speed, wind direction, and air temperature data were collected at the $1 \mathrm{~m}$ inlet elevation using an onsite meteorological tower (Campbell Scientific). Relative humidity data were provided by hygrometers (Campbell Scientific Model HMP45C) mounted $1.5 \mathrm{~m}$ above the ground and located near the study site at the Bonanza Creek Experimental Forest and Long-Term Ecological Research station (Chapin, 2007). Relative humidity data used in this study were collected at site LTER2.

\section{Nocturnal nitrogen oxide partitioning}

For simplicity of discussion, we refer to nocturnal nitrogen oxides as $\mathrm{NO}_{\mathrm{N}}$ and define them as the sum of $\mathrm{NO}_{3}+\mathrm{N}_{2} \mathrm{O}_{5}$. The formation of $\mathrm{NO}_{\mathrm{N}}$ is the result of oxidation of $\mathrm{NO}_{2}$ by ozone to form $\mathrm{NO}_{3}$, Reaction (R1). Subsequent conversion to $\mathrm{N}_{2} \mathrm{O}_{5}$ (Reaction $\mathrm{R} 2$ ) proceeds rapidly. For example, at $\mathrm{NO}_{2}$ levels of $5 \mathrm{ppbv},-20^{\circ} \mathrm{C}, 1$ atmosphere pressure, typical conditions during our study, the lifetime of $\mathrm{NO}_{3}$ with respect to the formation of $\mathrm{N}_{2} \mathrm{O}_{5}$ is $5 \mathrm{~s}$. In comparison, the thermal dissociation lifetime of $\mathrm{N}_{2} \mathrm{O}_{5}$ to form $\mathrm{NO}_{3}+\mathrm{NO}_{2}$ (Reaction R3) is $4 \mathrm{~h}$ (again at $-20^{\circ} \mathrm{C}$ ). The result is that $\mathrm{NO}_{\mathrm{N}}$ spends very little time as the nitrate radical before partitioning to $\mathrm{N}_{2} \mathrm{O}_{5}$, and $\mathrm{NO}_{\mathrm{N}} \approx \mathrm{N}_{2} \mathrm{O}_{5}$. Under typical study conditions, the $\mathrm{NO}_{3}$ abundance is negligible and the reactive losses of nitrate radical are generally too slow to compete with partitioning to $\mathrm{N}_{2} \mathrm{O}_{5}$. The only processes fast enough to compete for reaction of $\mathrm{NO}_{3}$ with formation of $\mathrm{N}_{2} \mathrm{O}_{5}$ is the fast reaction of $\mathrm{NO}$ with $\mathrm{NO}_{3}$ (Reaction R5) and to a lesser extent, the daytime photolysis of $\mathrm{NO}_{3}$. For example, the lifetime of $\mathrm{NO}_{3}$ with respect to reaction with $0.3 \mathrm{ppbv}$ $\mathrm{NO}$ is about $5 \mathrm{~s}$, while the lifetime with respect to photolysis $\left(j-\mathrm{NO}_{3}=0.2 \mathrm{~s}^{-1}\right)$ is also $5 \mathrm{~s}$ with overhead sun (FinlaysonPitts and Pitts, 2000). For NO levels greater than about 1 ppbv, the reactive sink of $\mathrm{NO}_{3}$ (with $\mathrm{NO}$ ) is very important as it becomes faster than formation of $\mathrm{N}_{2} \mathrm{O}_{5}$. Thus, only nighttime data at low $\mathrm{NO}$ will be considered for detailed lifetime analysis.

\section{Steady state lifetimes and other considerations}

Assuming rapid conversion of $\mathrm{NO}_{3}$ to $\mathrm{N}_{2} \mathrm{O}_{5}$ and little thermal dissociation of $\mathrm{N}_{2} \mathrm{O}_{5}$, valid during our study because at cold temperatures $k_{4}\left[\mathrm{~N}_{2} \mathrm{O}_{5}\right] \gg k_{3}\left[\mathrm{~N}_{2} \mathrm{O}_{5}\right]$, the kinetic expression for $\mathrm{N}_{2} \mathrm{O}_{5}$ is given by

$\frac{d\left[\mathrm{~N}_{2} \mathrm{O}_{5}\right]}{d t}=k_{1}\left[\mathrm{NO}_{2}\right]\left[\mathrm{O}_{3}\right]-k_{4}\left[\mathrm{~N}_{2} \mathrm{O}_{5}\right]$ 


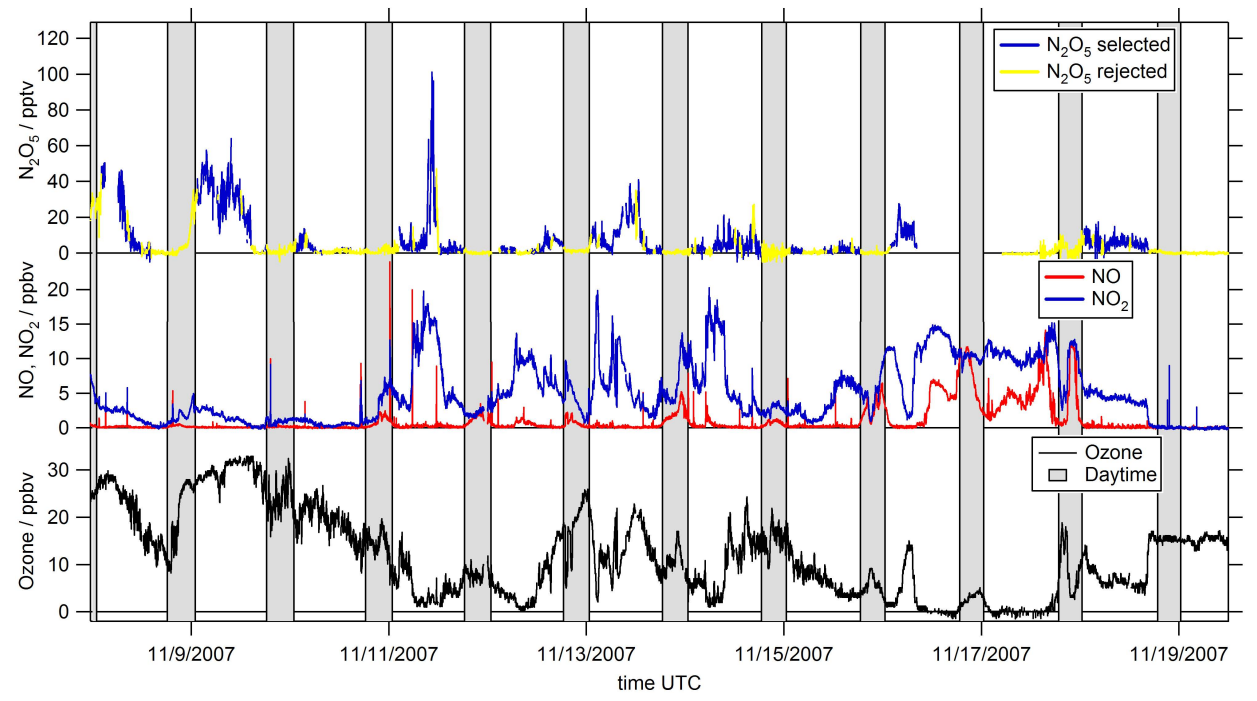

Fig. 2. Time series of $\mathrm{N}_{2} \mathrm{O}_{5}, \mathrm{NO}, \mathrm{NO}_{2}$, and ozone mixing ratios from the full campaign. $\mathrm{N}_{2} \mathrm{O}_{5}$ data are filtered as described in Sect. 5 and are colored blue for selected data and yellow for rejected data.

Assuming steady state for $\mathrm{N}_{2} \mathrm{O}_{5}$, this equation may be rearranged to

$\tau\left(\mathrm{N}_{2} \mathrm{O}_{5}\right)=\frac{1}{k_{4}}=\frac{\left[\mathrm{N}_{2} \mathrm{O}_{5}\right]}{k_{1}\left[\mathrm{NO}_{2}\right]\left[\mathrm{O}_{3}\right]}$.

Here, the symbol $\tau\left(\mathrm{N}_{2} \mathrm{O}_{5}\right)$ indicates the steady state lifetime of $\mathrm{N}_{2} \mathrm{O}_{5}$.

Brown et al. (2003) use a simple box model to demonstrate that the applicability of the steady state approximation to $\mathrm{NO}_{3}$ and $\mathrm{N}_{2} \mathrm{O}_{5}$ atmospheric observations depends upon the strength of sinks for $\mathrm{NO}_{3}$ and $\mathrm{N}_{2} \mathrm{O}_{5}$, the concentration of $\mathrm{NO}_{2}$, and the ambient temperature. Model results indicate that, in polluted air masses (i.e. large $\mathrm{NO}_{2}$ mixing ratios) and cold conditions, when $\mathrm{NO}_{3}$ and $\mathrm{N}_{2} \mathrm{O}_{5}$ sinks are weak, the approach to steady state can be slow. In the simulations of Brown et al. (2003), the timescale of the approach to steady state can exceed the duration of a typical dark period $(>12 \mathrm{~h})$. Under such conditions, the steady state approximation would not be valid. However, as will be shown below, if the losses of $\mathrm{N}_{2} \mathrm{O}_{5}$ are sufficiently fast, the system achieves steady state on a rapid timescale, and we argue that our data indicate that the system does achieve steady state.

In the case where $\mathrm{NO}_{3}$ losses can be ignored, the ratelimiting step for loss of $\mathrm{N}_{2} \mathrm{O}_{5}$ is the heterogeneous hydrolysis Reaction (R4). Therefore, the kinetic expression for $\mathrm{N}_{2} \mathrm{O}_{5}$ (Eq. 1) simplifies to an exponential approach to steady state with relaxation time (the time to reach $63 \%=1-e^{-1}$ of steady state) equal to the loss lifetime of $\mathrm{N}_{2} \mathrm{O}_{5}$. Generally, the behavior of $\mathrm{N}_{2} \mathrm{O}_{5}$ can be considered in the context of fast or slow losses. If losses of $\mathrm{N}_{2} \mathrm{O}_{5}$ are fast, then the system achieves steady state on a fast timescale. If losses of $\mathrm{N}_{2} \mathrm{O}_{5}$ are slow, then it is useful to consider the source rate of $\mathrm{NO}_{\mathrm{N}}$ (Reaction $\mathrm{R} 1$, with a rate of $k_{1}\left[\mathrm{NO}_{2}\right]\left[\mathrm{O}_{3}\right]$ ). This source rate is easily calculated from the observed data, and for the case of slow losses, the kinetic expression of $\mathrm{N}_{2} \mathrm{O}_{5}$ (Eq. 1) shows that $d\left[\mathrm{~N}_{2} \mathrm{O}_{5}\right] / d t$ is equal to the source rate. Thus, in the limit of short plume-processing times compared to the $\mathrm{N}_{2} \mathrm{O}_{5}$ loss lifetime, $\mathrm{N}_{2} \mathrm{O}_{5}$ should increase as the integral of its source rate. Therefore, we can examine the temporal behavior of $\mathrm{N}_{2} \mathrm{O}_{5}$ in an aged airmass to determine if it is near steady state or not. If the system has a short inferred lifetime and follows the source rate with lags on the order of the inferred lifetime, we would indicate that it is near steady state. Alternatively, if $\mathrm{N}_{2} \mathrm{O}_{5}$ increases as the integral of the source rate, the system is clearly not at steady state.

\section{Results}

Figure 2 shows the time series of $\mathrm{NO}, \mathrm{NO}_{2}, \mathrm{O}_{3}, \mathrm{~N}_{2} \mathrm{O}_{5}$ for the entirety of the campaign. All data are recorded at instrument-native time resolutions (typically $1-2 \mathrm{~s}$ ) and averaged to $1 \mathrm{~min}$ data for analysis. $\mathrm{N}_{2} \mathrm{O}_{5}$ abundance (upper panel) varies from a maximum near 100 pptv (parts per trillion by volume) to sub-detection limit. When $\mathrm{N}_{2} \mathrm{O}_{5}$ is present, diurnal variation is evident with lower levels during the day (shaded background regions) and highest levels occurring at night. However, note that when NO is low in the day, the low sunlight intensity of late November in Fairbanks $\left(65^{\circ} \mathrm{N}\right)$ allows significant $\mathrm{N}_{2} \mathrm{O}_{5}$ levels to exist in the day. $\mathrm{NO}_{2}$ and $\mathrm{NO}$ levels range from near zero to a maximum of about 20 ppbv. Low levels of fresh pollution at the study site are evidenced by the low levels of NO for most of the study. A notable exception of $\mathrm{NO}$ occurring at night was observed during a highly polluted "ozone titration" event on 16 and 17 November. Ozone levels range from below the instrumental detection limit to around 35 ppbv. Regional background 
ozone levels in the Fairbanks area during November are typically near $35 \mathrm{ppbv}$, and thus we observe significant $\mathrm{O}_{3}$ losses, most probably contributed to by the nocturnal ozone loss associated with the dark $\mathrm{NO}_{\mathrm{x}}$ oxidation pathway (Brown et al., 2006a).

As discussed above, certain conditions are amenable to formation of $\mathrm{N}_{2} \mathrm{O}_{5}$, and thus we want to identify conditions where $\mathrm{N}_{2} \mathrm{O}_{5}$ should be forming, enabling the observation of its loss processes. We color the $\mathrm{N}_{2} \mathrm{O}_{5}$ data in Fig. 2 and all subsequent plots by the code of yellow for "rejected" values, where trivial losses of $\mathrm{N}_{2} \mathrm{O}_{5}$ preclude lifetime analysis, and dark blue for "selected" values, where $\mathrm{N}_{2} \mathrm{O}_{5}$ should be forming sufficiently rapidly to warrant lifetime analysis. The conditions we use to identify selected data are: 1) The sun is below the horizon. 2) NO is less than 1 ppbv, the approximate limit quantification of the $\mathrm{NO}_{\mathrm{x}}$ analyzer. Exceeding this threshold would indicate that the airmass is titrated of ozone or impacted by a local plume. Furthermore, at $1 \mathrm{ppbv}$ NO the rate of Reaction (R5) (destruction of $\mathrm{NO}_{3}$ ) exceeds the rate of Reaction (R2) (formation of $\mathrm{N}_{2} \mathrm{O}_{5}$ ) and, as a result, very low levels of $\mathrm{NO}_{\mathrm{N}}$ would be present in the air mass. 3) Both of these conditions have been valid for at least a half hour. And 4) that the source rate of $\mathrm{N}_{2} \mathrm{O}_{5}$ is more than $10 \mathrm{pptv} / \mathrm{hr}$, which is meant to preclude analysis of very clean (unpolluted) air masses.

\section{Discussion}

\subsection{Validity of the steady state approximation}

Steady state lifetimes were calculated for the entirety of the study, using $\mathrm{N}_{2} \mathrm{O}_{5}, \mathrm{NO}_{2}$, and $\mathrm{O}_{3}$ measurements and temperature-dependent values for $k_{1}$ based on NASA/JPL recommendations (Sander et al., 2006). Lifetimes ranged from sub-minute to roughly $2 \mathrm{~h}$, with a median value of about $10 \mathrm{~min}$. These values are in agreement with previous measurements in Fairbanks (Ayers and Simpson, 2006). Figure 3 shows the steady state lifetimes, $\mathrm{N}_{2} \mathrm{O}_{5}$ source rate, and $\mathrm{N}_{2} \mathrm{O}_{5}$ abundance for two selected periods during the study and can be used to further confirm the applicability of the steady state approximation.

In Fig. 3, period $\mathrm{I}$ is an example of times where $\mathrm{N}_{2} \mathrm{O}_{5}$ abundance was elevated (greater than $20 \mathrm{pptv}$ ) and when longer steady state lifetimes were observed (20 to $60 \mathrm{~min}$ ). Period II is representative of periods with suppressed $\mathrm{N}_{2} \mathrm{O}_{5}$ abundance (less than $20 \mathrm{pptv}$ ) and short steady state lifetimes (less than $20 \mathrm{~min}$ ). The absence of $\mathrm{N}_{2} \mathrm{O}_{5}$ in the early times of periods I and II is due to rapid losses associated with daytime conditions (reaction with daytime $\mathrm{NO}$ and $\mathrm{NO}_{3}$ photolysis). As nightfall occurs, the build-up of $\mathrm{N}_{2} \mathrm{O}_{5}$ progresses until shortly after sunset when $\mathrm{N}_{2} \mathrm{O}_{5}$ levels stabilize and reach relatively steady conditions, clearly following source rate fluctuations with only small lags.
Multiple lines of arguments support the validity of the steady state analysis. First, based on measurements made at the study site and review of National Weather Service radiosonde data from the Fairbanks airport, wind speeds in the lowest $1200 \mathrm{~m}$ of the troposphere were typically below $3 \mathrm{~m} / \mathrm{s}$ for the entirety of the study. Thus, the shortest processing times for air masses can be estimated by considering that the nearest $\mathrm{NO}_{\mathrm{x}}$ source is minimally $20 \mathrm{~km}$ upwind (depending upon actual airmass trajectory). At maximal windspeeds, a minimum transport time of $2 \mathrm{~h}$ is required for the airmass to reach the study site. Therefore, most air masses are more aged than a couple hours, allowing sufficient time for steady state lifetimes of less than a few hours to be observed. However, we observe steady state lifetimes on the order of tens of minutes, indicating losses on timescales shorter than typical transport times.

Second, the discussion above indicated that if the actual lifetime of $\mathrm{N}_{2} \mathrm{O}_{5}$ is long compared to the processing timescale, the temporal behavior of $\mathrm{N}_{2} \mathrm{O}_{5}$ should be increasing as the integral of the source rate. We do not observe the $\mathrm{N}_{2} \mathrm{O}_{5}$ mixing ratio behaving as the integral of the source rate, but instead following the source rate on the timescale of less than an hour. The representative data in Fig. 3 demonstrates that the hourly source of $\mathrm{N}_{2} \mathrm{O}_{5}$ is generally greater than the measured $\mathrm{N}_{2} \mathrm{O}_{5}$ mixing ratio, indicating that the $\mathrm{N}_{2} \mathrm{O}_{5}$ abundance would be produced in an hour or less. Considering that the typical transport time was greater than $2 \mathrm{~h}$, yet the detected $\mathrm{N}_{2} \mathrm{O}_{5}$ abundance was significantly less than the expected cumulative production, the clear indication is the presence of a significant $\mathrm{N}_{2} \mathrm{O}_{5}$ loss. The loss occurs on the timescale of an hour or less, again validating the idea that these air masses have had sufficient time to reach steady state.

Third, referring to Fig. 2, we can consider that nearly all of these air masses have experienced loss of odd oxygen $\left(\mathrm{O}_{\mathrm{x}}=\mathrm{NO}_{2}+\mathrm{O}_{3}\right)$. For fresh pollution at night, $\mathrm{O}_{\mathrm{x}}$ is conserved (Brown et al., 2006a), and thus loss of $\mathrm{O}_{\mathrm{x}}$ indicates chemical aging. For each molecule of $\mathrm{N}_{2} \mathrm{O}_{5}$ hydrolyzed, three molecules of $\mathrm{O}_{\mathrm{x}}$ are lost. Thus, the loss of $\mathrm{O}_{\mathrm{x}}$ is three times the formation rate of $\mathrm{N}_{2} \mathrm{O}_{5}$. Accounting for dilution limiting $\mathrm{O}_{\mathrm{x}}$ loss at our study site, we estimate that polluted plumes experience initial nighttime $\mathrm{O}_{\mathrm{x}}$ loss at rates of about $1 \mathrm{ppbv} / \mathrm{hr}$. Many of the observed air masses had significant $\mathrm{O}_{\mathrm{x}}$ loss ( $>10 \mathrm{ppbv} \mathrm{O}_{\mathrm{x}}$ loss from the regional background of $\approx 35$ ppbv). Subsequently, these air masses appear significantly aged, often more than $10 \mathrm{~h}$.

All of the evidence presented in Figs. 2 and 3 suggest that $\mathrm{N}_{2} \mathrm{O}_{5}$ losses are significantly strong to allow $\mathrm{NO}_{\mathrm{N}}$ to achieve steady state rapidly (on the same timescale as the lifetime), and that the steady state approximation is generally valid during our study period. 

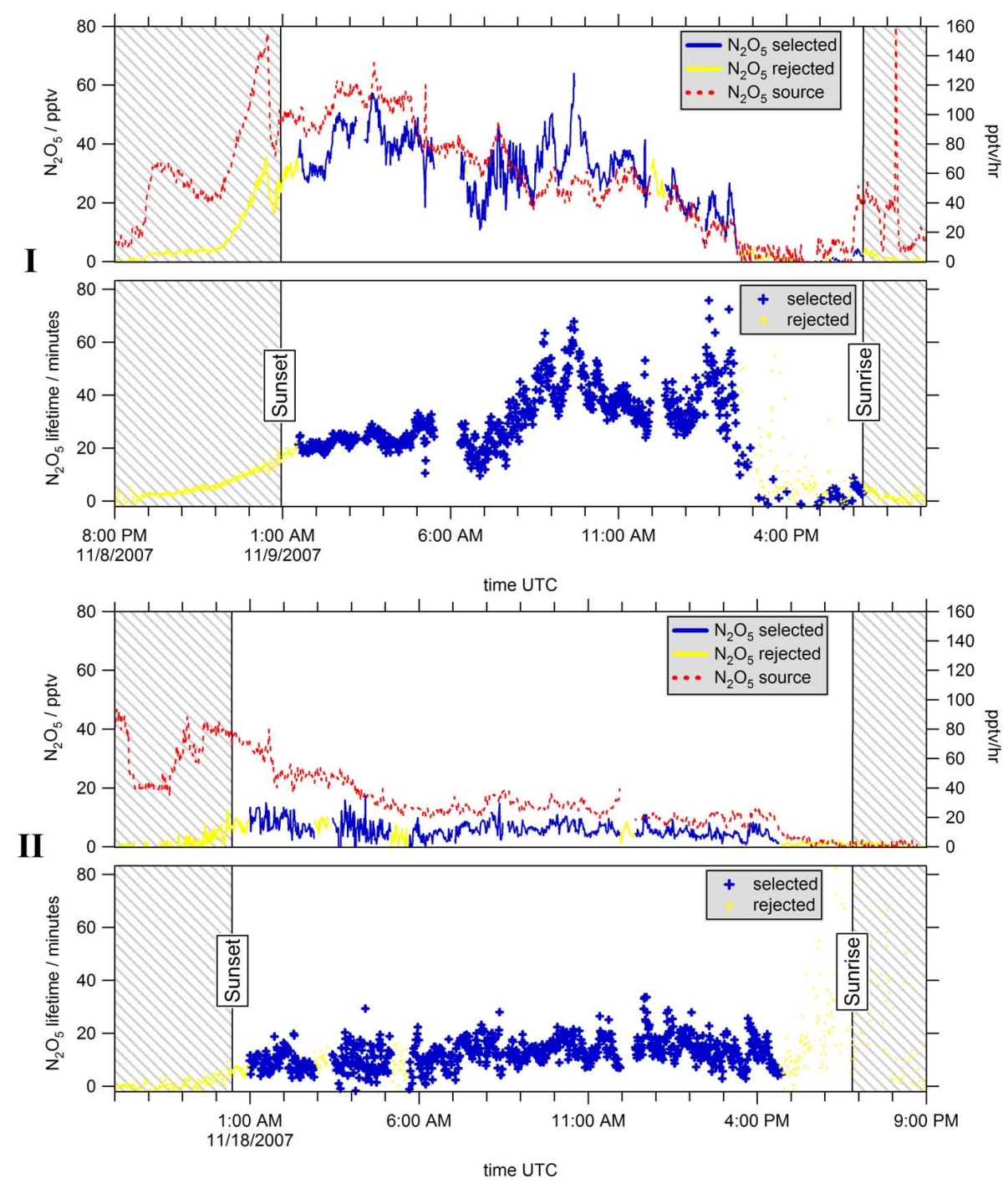

Fig. 3. $\mathrm{N}_{2} \mathrm{O}_{5}$ steady state lifetimes, source rates, and mixing ratios for two representative periods of the campaign. $\mathrm{N}_{2} \mathrm{O}_{5}$ mixing ratios and $\tau\left(\mathrm{N}_{2} \mathrm{O}_{5}\right)$ are colored to differentiate rejected (yellow) and selected (blue) data. Period I is representative of times where $\mathrm{N}_{2} \mathrm{O}_{5}$ abundance was elevated and $\tau\left(\mathrm{N}_{2} \mathrm{O}_{5}\right)$ reached its higher limits. Period II is representative of times where $\mathrm{N}_{2} \mathrm{O}_{5}$ abundance was suppressed and $\tau\left(\mathrm{N}_{2} \mathrm{O}_{5}\right)$ were short. Period I clearly shows $\mathrm{N}_{2} \mathrm{O}_{5}$ building to steady levels soon after sunset. Note that at no point in either time series does $\mathrm{N}_{2} \mathrm{O}_{5}$ build at the source rate (top, right axis), an indication of rapid loss of $\mathrm{N}_{2} \mathrm{O}_{5}$.

\subsection{Loss of $\mathrm{N}_{2} \mathrm{O}_{5}$ and relative humidity with respect to ice}

Time series of $\mathrm{N}_{2} \mathrm{O}_{5}$ mixing ratios (top trace) and relative humidity with respect to ice ( $\mathrm{RH}$, bottom) covering the duration of the study are presented in Fig. 4. Figure 4 shows a clear anticorrelation between $\mathrm{N}_{2} \mathrm{O}_{5}$ abundance and $\mathrm{RH}$. When $\mathrm{RH}$ is less than $100 \%, \mathrm{~N}_{2} \mathrm{O}_{5}$ abundance sometimes reaches its highest levels. Conversely, when RH is greater than $100 \%$, $\mathrm{N}_{2} \mathrm{O}_{5}$ abundance is generally suppressed, even though our selection criteria assure that conditions are favorable for formation of $\mathrm{N}_{2} \mathrm{O}_{5}$.
Figure 5 shows the dependence of the $\mathrm{N}_{2} \mathrm{O}_{5}$ steady-state lifetime on the relative humidity with respect to ice. In this and further analysis, we present lifetimes on logarithmic axes because the distribution of lifetimes is very broad and grouping data in this manner leads to nearly normal (Gaussian) distributions. In this plot, we see that sub-saturated air masses show longer lifetimes than ice-saturated air masses. From the plot, it is clear that there are many points that are icesaturated but near $100 \%$ RH. This behavior is expected because once ice nucleates, water vapor will condense on the ice crystal, holding the RH near saturation. On the other hand, sub-saturated air masses will not have ice present, and 


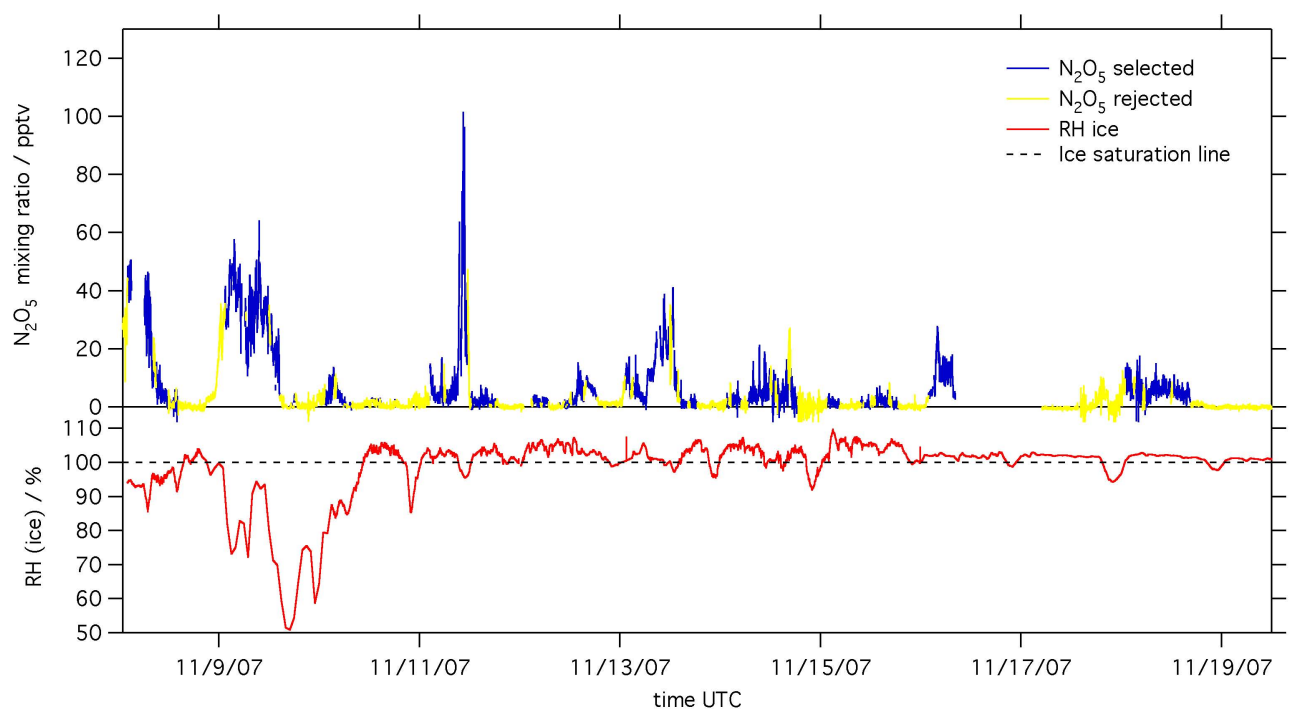

Fig. 4. Time series of $\mathrm{N}_{2} \mathrm{O}_{5}$ mixing ratios (upper panel) for the duration of the study. The $\mathrm{N}_{2} \mathrm{O}_{5}$ data were colored based on the selection criteria described in Sect. 5. The lower panel is a time series of relative humidity with respect to ice (RH). Note the apparent anticorrelation between $\mathrm{N}_{2} \mathrm{O}_{5}$ abundance and $\mathrm{RH}$.

can take on a wider range of $\mathrm{RH}$ values. We analyze the data in two regions, ice-saturated and sub-saturated, and find nearly a factor of three difference in the mean log-lifetime.

Figure 6 shows the same data replotted as normalized histograms of observed $\mathrm{N}_{2} \mathrm{O}_{5}$ lifetime distributions either at ice-saturated or sub-saturated humidities. The ice-saturated (RH $>100 \%)$ population, shown in blue in Fig. 6, has a peak value of about $6 \mathrm{~min}$. The sub-saturated $(\mathrm{RH}<100 \%)$ population, shown in red, has a peak value near $20 \mathrm{~min}$. Significance testing rejected the null hypothesis that the two populations' means were the same, with a confidence interval at more than $99.9 \%$. Thus, the difference between the ice-saturated and sub-saturated populations is significant and shows that ice formation plays a major role in the loss of $\mathrm{N}_{2} \mathrm{O}_{5}$.

Two possible hypotheses could explain the observed dependence of the $\mathrm{N}_{2} \mathrm{O}_{5}$ lifetime on the relative humidity with respect to ice. First it is possible that when airmasses become supersaturated with respect to ice, they nucleate a large surface area of ice, which then acts as a surface for heterogeneous hydrolysis of $\mathrm{N}_{2} \mathrm{O}_{5}$. An alternative hypothesis takes the RH with respect to ice as a proxy for airmass contact with the snowpack. If an airmass comes in contact with snowpack, it will equilibrate to having $100 \%$ saturation with respect to that snow, either through sublimation or condensation, depending upon whether the airmass was sub- or super-saturated before contact. On the other hand, airmasses that have no contact with the snowpack, say descending from aloft recently, could be sub-saturated with respect to ice. Therefore, it may be the case that RH with respect to ice is an indicator of degree of airmass contact with

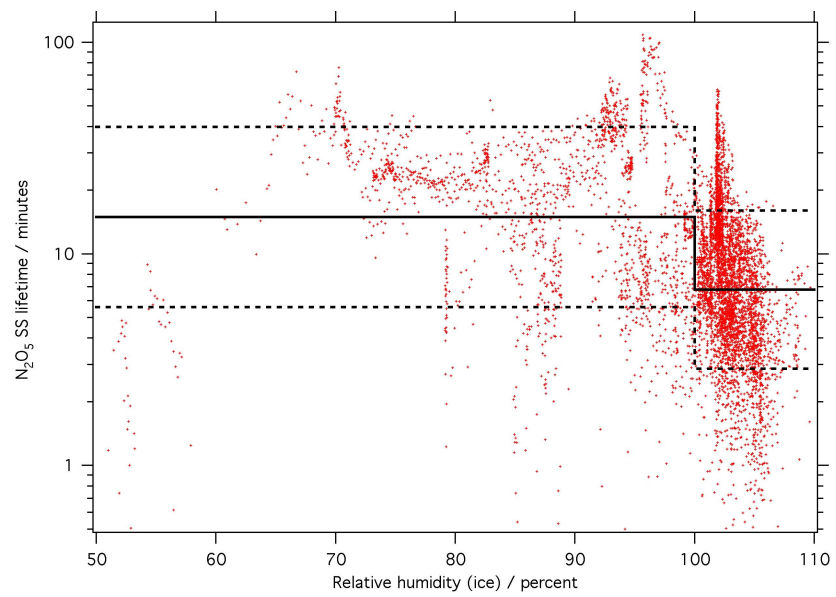

Fig. 5. The dependence of the $\mathrm{N}_{2} \mathrm{O}_{5}$ steady-state lifetime on the relative humidity with respect to ice. The red points correspond to individual "selected" $\mathrm{N}_{2} \mathrm{O}_{5}$ steady-state lifetimes. The black line shows the mean of the log-lifetime distribution within the classes of sub-saturated and ice-saturated airmasses. The dashed lines represent \pm 1 -sigma of the distribution of log-lifetimes.

the snowpack with very near saturated (or slightly supersaturated) airmasses having had recent contact with the snowpack and drier airmasses indicative of descent of air from aloft and less snowpack contact. In the following two sections, we explore these two hypotheses. 


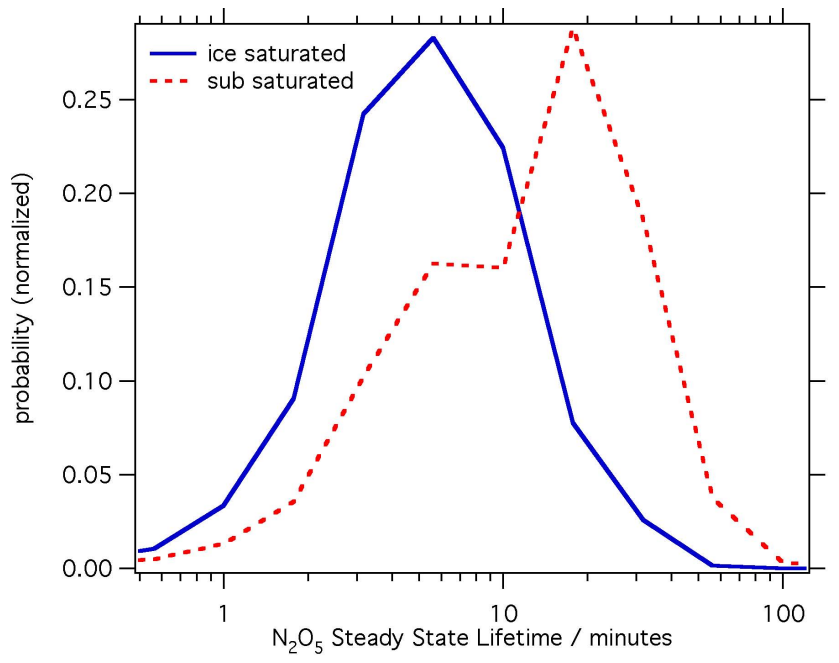

Fig. 6. Normalized histograms of $\tau\left(\mathrm{N}_{2} \mathrm{O}_{5}\right)$ for selected data split into populations where $\mathrm{RH}$ was greater than $100 \%$ (blue, solid line) and where RH was less than $100 \%$ (red, dashed line). The peak value for the ice-saturated lifetimes is near $6 \mathrm{~min}$ and is significantly shorter than the peak value for the sub-saturated lifetimes, which is near $20 \mathrm{~min}$.

\subsection{Loss of $\mathrm{N}_{2} \mathrm{O}_{5}$ on suspended ice particles}

For relative humidity with respect to ice less than $100 \%$, ice should evaporate, thermodynamically, and suspended ice particles should not be present. When air cools and RH supersaturates, that is, becomes greater than $100 \%$, ice crystals should thermodynamically form. However, nucleation of ice crystals can be a significant barrier to ice crystal formation, allowing RH to exceed $100 \%$. Curry et al. (1990) indicate that at cold temperatures particles often nucleate near the thermodynamic threshold. Therefore, we use a threshold of $100 \%$ to separate conditions that may have suspended ice particles from those that cannot have ice present.

The observed $\mathrm{N}_{2} \mathrm{O}_{5}$ lifetimes, in combination with particle surface area can provide an estimate of the $\mathrm{N}_{2} \mathrm{O}_{5}$ uptake coefficient, $\gamma\left(\mathrm{N}_{2} \mathrm{O}_{5}\right)$. The uptake coefficient describes the efficiency with which $\mathrm{N}_{2} \mathrm{O}_{5}$ undergoes heterogeneous hydrolysis per collision with particles. For particles less than $1 \mu \mathrm{m}$ diameter, which do not suffer kinetic limitation by mass transport, the reactive uptake coefficient is given by

$\gamma\left(\mathrm{N}_{2} \mathrm{O}_{5}\right)=\frac{4}{\bar{c} A \tau\left(\mathrm{N}_{2} \mathrm{O}_{5}\right)}$.

Here, $\bar{c}$ is the mean molecular speed of $\mathrm{N}_{2} \mathrm{O}_{5}$, and $A$ is the aerosol surface area density.

Ice particle concentrations have been measured to exceed $1000 \mathrm{~L}^{-1}\left(=1 \mathrm{~cm}^{-3}\right)$ in the Arctic (Girard et al., 2005; Curry et al., 1990; Ohtake et al., 1982). Studies of polluted air masses in the Arctic and ice particle size distribution measurements are scarce but have been measured by Benson (1965), who measured ice particles to be between
5 and $10 \mu \mathrm{m}$, and Ohtake and Huffman (1969), who measured ice fog ice particles between 4 and $6 \mu \mathrm{m}$ modal radius. Ice crystal concentration size distributions were used to infer a modal radius of $10 \mu \mathrm{m}$ by Witte (1968) during aircraft measurements in Barrow, Alaska. Gotaas and Benson (1965) cite a radius of $25 \mu \mathrm{m}$ for a radiative cooling study in the Fairbanks area. These values span a fairly wide range but are on the order of a $10 \mu \mathrm{m}$ modal radius $(20 \mu \mathrm{m}$ diameter) with number densities of a up to $\approx 1$ particle per $\mathrm{cm}^{3}$. Spherical particles with $20 \mu \mathrm{m}$ diameters have a surface area of $\approx 1250 \mu \mathrm{m}^{2} /$ particle and non-spherical shapes of the same volume would have higher surface areas per particle, thus suspended ice surface area densities could easily exceed $1000 \mu \mathrm{m}^{2} / \mathrm{cm}^{3}$. For our location, the presence of pollution aerosol particles might cause an increased number of particles to form, which also may be smaller due to spreading the available condensed water across more ice particles. This effect was predicted by Twomey (1974), and has been observed in satellite observations that show pollution suppresses rain and snow (Rosenfeld, 2000; Toon, 2000). Both increased ice particle number and decreased size would increase the surface area significantly and decrease fall rates, resulting in increased atmospheric lifetimes for the particles. Therefore, it is likely that significantly more than $1000 \mu \mathrm{m}^{2} / \mathrm{cm}^{3}$ polluted ice surface area density is present in ice-saturated air masses.

Even with some size reduction, ice particles may not be in the submicron size range, and Eq. (3) would then not be directly applicable due to mass transport limitations. However, because the size of the particles is probably near the micron size threshold, we feel it is useful to consider the magnitude of the inferred reactive uptake coefficient $(\gamma)$ using a lifetime of $6 \mathrm{~min}$ (the peak of the ice-saturated data) and an $A$ of $\approx 1000 \mu \mathrm{m}^{2} / \mathrm{cm}^{3}$. In this limit, one arrives at an estimate of 0.05 for $\gamma\left(\mathrm{N}_{2} \mathrm{O}_{5}\right)$ on polluted ice particles. While not quantitative, this estimate is in reasonable agreement with laboratory and ambient observations of $\gamma\left(\mathrm{N}_{2} \mathrm{O}_{5}\right)$ with respect to aerosol particles (Hanson and Ravishankara, 1991; Hallquist et al., 2000; Mentel et al., 1999; Leu, 2003; Brown et al., 2006b). A better estimate of the reactive uptake coefficient is not possible because we do not know the size of the particles nor their abundance. Thus, we simply note that reaction on suspended ice surfaces is a feasible scenario based upon past work on ice particulate pollution in Fairbanks. It is important to consider the state of the surface of the ice particles. The particles are formed in a polluted airmass that contains at least partially soluble aerosol particles. Measurements of Fairbanks pollution indicate approximately $20 \%$ of the aerosol particle mass is sulfate (Di Genova and Dulla, 2007). Sulfate that would nucleate or stick to ice particles would be expected to partition to the surface and locally melt the ice surface. Therefore, ice particles forming in polluted and ice-saturated air masses are unlikely to be pure ice. Instead, the ice particles are likely to have surfaces coated with concentrated aqueous solutions containing sulfate, which have been shown to have relatively high surface 


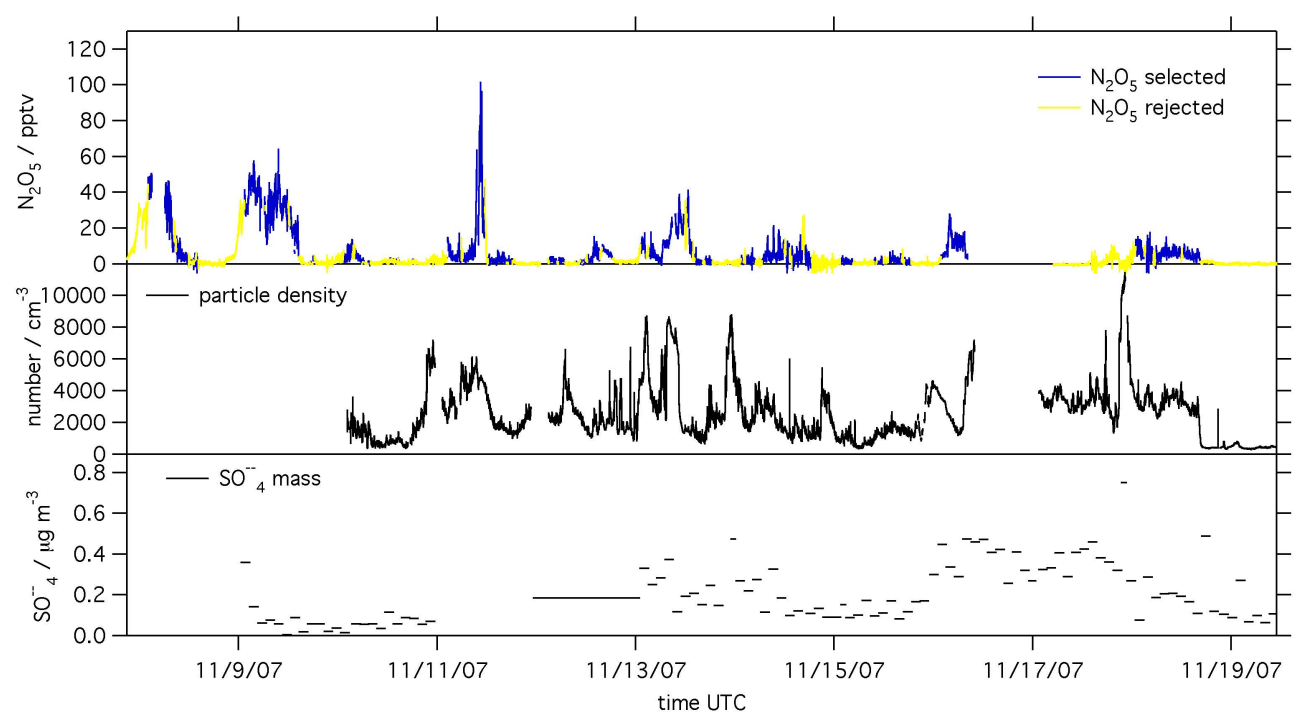

Fig. 7. Time series of $\mathrm{N}_{2} \mathrm{O}_{5}$ mixing ratios and directly measured aerosol properties.

reactivity from ambient observations (Brown et al., 2006b). Undoubtedly, further studies characterizing ice particle surface area density are required to quantify the role of ice particles in the removal of $\mathrm{N}_{2} \mathrm{O}_{5}$ from the atmosphere. However, the significant difference we observe between ice-saturated and sub-saturated $\mathrm{N}_{2} \mathrm{O}_{5}$ lifetimes clearly indicates that ice has a significant effect on $\mathrm{N}_{2} \mathrm{O}_{5}$ heterogeneous hydrolysis.

\subsection{Loss of $\mathrm{N}_{2} \mathrm{O}_{5}$ on snowpack}

As discussed earlier, an alternative hypothesis is that the RH with respect to ice is an indicator of dynamic contact of airmasses with the snowpack. In this hypothesis, we would expect that saturated airmasses had recent contact with the snowpack, and short $\mathrm{N}_{2} \mathrm{O}_{5}$ lifetimes may then indicate deposition of $\mathrm{N}_{2} \mathrm{O}_{5}$ to the ice surfaces in the snowpack. The longer lifetimes representative of drier airmasses may then be indicative of losses on other surfaces or less dynamic contact with the surface. We know of no measurements of the deposition velocity of $\mathrm{N}_{2} \mathrm{O}_{5}$ to snow surfaces, but measurements of deposition of $\mathrm{HNO}_{3}$ indicate deposition velocities on the order of $1-2.5 \mathrm{~cm} \mathrm{~s}^{-1}$ (Levy and Moxim, 1989). The boundary layer is generally very stable during nighttime in these data due to strong radiative cooling from the snow surface and low wind speeds, so it is not easy to define a well-mixed surface layer from which $\mathrm{N}_{2} \mathrm{O}_{5}$ would deposit. However, if we take the lowest $5 \mathrm{~m}$ of the atmosphere to be well mixed and a deposition velocity of $1 \mathrm{~cm} \mathrm{~s}^{-1}$, the $\mathrm{N}_{2} \mathrm{O}_{5}$ lifetime would be $500 \mathrm{~s}$ or about $8 \mathrm{~min}$. This timescale is similar to the observed lifetime of $\mathrm{N}_{2} \mathrm{O}_{5}$ for ice-saturated airmasses, so it appears feasible that deposition to the ice in the snowpack is responsible for the rapid loss of $\mathrm{N}_{2} \mathrm{O}_{5}$ under ice-saturated conditions. The longer lifetimes observed under unsaturated conditions would then be indicative of less turbulent contact with the surface.

\subsection{Loss of $\mathrm{N}_{2} \mathrm{O}_{5}$ with respect to aerosol particles}

A third hypothesis would be that $\mathrm{N}_{2} \mathrm{O}_{5}$ losses occur on submicron aerosol particles, as has been considered under warm conditions (Brown et al., 2006b). Our observations of aerosol particles did not include a direct measurement of the aerosol surface area density; therefore, other aerosol measurements were used to constrain estimates of the aerosol surface area density and to consider losses of $\mathrm{N}_{2} \mathrm{O}_{5}$ on aerosol particles. The aerosol particle measurements were carried out in a heated shelter, and thus, any ice particles that may have been sampled would have evaporated, and we would measure only their non-volatile nuclei. Volatilization can also result in under-determination of semi-volatile compounds (e.g. nitric acid) in ice particle nuclei or aerosol particulate matter. Therefore, the following analysis is focused solely on the data derived from collection of non-volatile sulfate aerosol particles.

If $\mathrm{N}_{2} \mathrm{O}_{5}$ losses on aerosol dominate, the expected result would be an anticorrelation between $\tau\left(\mathrm{N}_{2} \mathrm{O}_{5}\right)$ and aerosol surface area, where lifetimes would be shorter in the presence of higher surface areas. Figure 7 shows a time series of the $\mathrm{N}_{2} \mathrm{O}_{5}$ mixing ratio with two directly measured aerosol properties, particle number density and total submicron sulfate mass concentration. The aerosol data start later than the $\mathrm{N}_{2} \mathrm{O}_{5}$ measurements, and are sometimes missing due to equipment operations or malfunctions. The sulfate 


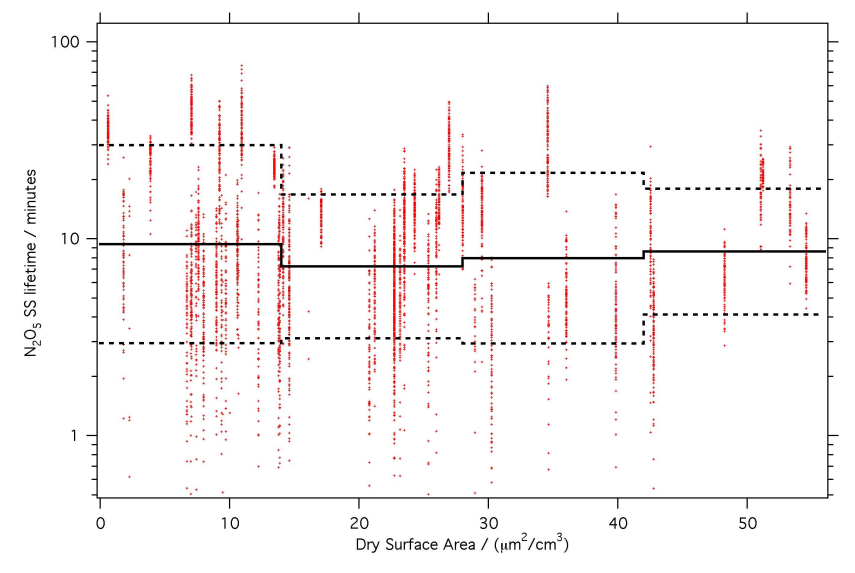

Fig. 8. The relationship between aerosol surface area and $\mathrm{N}_{2} \mathrm{O}_{5}$ lifetime. The red points correspond to individual "selected" $\mathrm{N}_{2} \mathrm{O}_{5}$ steady-state lifetimes as a function of aerosol surface area derived from the modified drum data. The black line shows the mean of the log-lifetime distribution within each of four bins covering the observed range of aerosol surface areas, and the dashed lines represent \pm 1 -sigma of the distribution of log-lifetimes. The data fail to show an anticorrelation between aerosol surface area and $\mathrm{N}_{2} \mathrm{O}_{5}$ lifetime. See text for details.

data are derived from the modified drum instrument and generally have 2 -h time resolution, leading to a discontinuous appearance. On 12 November, the aerosol instrument malfunctioned leading to a single 24-h sample. While Fig. 4 showed a visible anticorrelation between $\mathrm{N}_{2} \mathrm{O}_{5}$ and ice saturation, these data (Fig. 7) fail to show clear anticorrelation with aerosol abundance.

The size-resolved sulfate mass concentration data were converted to aerosol surface area estimates as described below. Sulfate was only present in the two smaller size bins, which measure particles 0.12 to $0.30 \mu \mathrm{m}$ diameters (geometric mean diameter $0.19 \mu \mathrm{m}$ ) and 0.30 to $0.84 \mu \mathrm{m}$ diameters (geometric mean diameter $0.50 \mu \mathrm{m}$ ). The majority, $60 \%$, of the mass was in the smaller size range, with the remaining $40 \%$ in the larger submicron size bin. The raw measurement is the sulfate aerosol concentration $\left(\mu \mathrm{g} / \mathrm{m}^{3}\right)$, which is converted to an estimated total particulate concentration in each size bin by dividing by the ratio of sulfate to total particulate mass. The total aerosol concentration, for each of the size bins, is then converted to a surface area based upon spherical particles with a density of $1 \mathrm{~g} / \mathrm{cm}^{3}$ at the mean geometric diameter of the size bin. The surface area is dominated by the smallest bin, which contains $80 \%$ of the surface area, with a small contribution by the middle bin (20\%). The campaign average aerosol surface area is $24 \mu \mathrm{m}^{2} / \mathrm{cm}^{3}$. Figure 8 shows the relationship between the $\mathrm{N}_{2} \mathrm{O}_{5}$ steady-state lifetime and the aerosol surface area. No obvious anticorrelation is seen in these data, so we attempted to bin the data into four levels of aerosol surface area. The black line shows the mean of the log-lifetime distribution in each of these four bins, while the dashed lines show \pm one standard deviation of log-lifetime. No significant trending of the lifetime is observed in these data, again indicating that aerosol surface area does not appear to be controlling the $\mathrm{N}_{2} \mathrm{O}_{5}$ lifetime. It is possible that high variability in the reactive uptake coefficient on aerosol particles would act to mask a direct relationship with aerosol surface area. In fact, Brown et al. (2006b) observed a large variability in $\gamma\left(\mathrm{N}_{2} \mathrm{O}_{5}\right)$ when changing between Ohio River Valley acidic sulfate aerosol and maritime aerosols. However, in our study, there is one dominant source of aerosol, Fairbanks pollution, which would be expected to have more constant aerosol properties than the aircraft-sampled data reported by (Brown et al., 2006b).

The report by Di Genova and Dulla (2007) indicates that less than $10 \%$ of the total aerosol mass in Fairbanks is from nitrate. The Di Genova and Dulla (2007) methods were based upon filter sampling, which could under-sample nitrate due to revolatalization, and thus there could be more nitrate in the actual aerosol. However, it is difficult to attribute the short $\mathrm{N}_{2} \mathrm{O}_{5}$ lifetimes observed during our study to suppression of the nitrate effect (Mentel et al., 1999) at high RH. Given the cold conditions of our study (typically -10 to $-30^{\circ} \mathrm{C}$ ) and RH with respect to ice (Fig. 4), it is likely that the majority of the water associated with the aerosol particle was frozen, and similarly to the discussion above for sulfate and ice particles, aerosol particles are likely to have surfaces coated with concentrated nitrate solutions, potentially increasing the nitrate effect on $\mathrm{N}_{2} \mathrm{O}_{5}$ hydrolysis.

To estimate the $\mathrm{N}_{2} \mathrm{O}_{5}$ reactive uptake coefficients on aerosol particles, we again refer to Eq. (3). Estimates for aerosol surface area density, $A$, were arrived at using two independent methods. First, we used the average surface area, $24 \mu \mathrm{m}^{2} / \mathrm{cm}^{3}$, calculated from the modified drum impactor data. Alternatively, as a check of these calculations, we converted the condensation particle counter number density data to an inferred surface area using published tri-modal log-normal particle size distributions. Parameters for this conversion were taken from Seinfeld and Pandis (1998) for "urban" and "rural" pollution. The urban and rural distributions give differing estimates of surface area of 31 and $54 \mu \mathrm{m}^{2} / \mathrm{cm}^{3}$, respectively, and while the estimation is clearly crude, it indicates that dry aerosol surface areas are relatively small. While these various estimates of aerosol surface area are only semi-quantitative, because of the necessity to make assumptions regarding the aerosol properties, each estimate gives surface area densities that are maximally around $50 \mu \mathrm{m}^{2} / \mathrm{cm}^{3}$. The resultant estimates for $\gamma\left(\mathrm{N}_{2} \mathrm{O}_{5}\right)$, assuming all losses occur on aerosol particles, would be approximately equal to unity, more than an order of magnitude higher than other observed values (Hanson and Ravishankara, 1991; Hallquist et al., 2000; Mentel et al., 1999; Leu, 2003; Brown et al., 2006b). Therefore, the large losses of $\mathrm{N}_{2} \mathrm{O}_{5}$ observed in our study are not readily explained by particulate pollution in the cold Fairbanks pollution plume. Instead, the lack 
of anticorrelation of $\mathrm{N}_{2} \mathrm{O}_{5}$ lifetime with particle counts and sulfate mass, in addition to estimates of surface area indicating that aerosol particles are insufficient to explain losses of $\mathrm{N}_{2} \mathrm{O}_{5}$ using laboratory values of $\gamma\left(\mathrm{N}_{2} \mathrm{O}_{5}\right)$, supports the idea that other surfaces are important for $\mathrm{N}_{2} \mathrm{O}_{5}$ losses in cold high-latitude plumes. We find that the presence of ice is correlated with $\mathrm{N}_{2} \mathrm{O}_{5}$ losses and hypothesize that the responsible ice surfaces exist either in the seasonal snowpack or as suspended ice particles. Further study of these two loss mechanisms is clearly needed.

\section{Conclusions}

We have presented the first direct observations implicating ice as being the surface that catalyzes heterogeneous hydrolysis of $\mathrm{N}_{2} \mathrm{O}_{5}$ in the cold, nighttime boundary layer at high latitudes. The observations show a strong anticorrelation for both $\mathrm{N}_{2} \mathrm{O}_{5}$ abundance and $\tau\left(\mathrm{N}_{2} \mathrm{O}_{5}\right)$ when compared to relative humidity with respect to ice. When the RH is greater than $100 \%$ and ice is likely present, $\tau\left(\mathrm{N}_{2} \mathrm{O}_{5}\right)$ is short and $\mathrm{N}_{2} \mathrm{O}_{5}$ levels are suppressed. On the other hand, when the $\mathrm{RH}$ is less than $100 \%$, ice is probably absent and $\tau\left(\mathrm{N}_{2} \mathrm{O}_{5}\right)$ is long and $\mathrm{N}_{2} \mathrm{O}_{5}$ levels are elevated. The difference between the peaks of these two lifetime distributions is approximately a factor of three. Seasonal snowpack holds the air in the boundary layer nearly saturated with respect to ice for much of the cold season (Andreas et al., 2002). Nighttime cooling may then form small ice particles and pollution may also produce increased numbers of ice nuclei that could increase the number and decrease the size of ice particles as well as modify the chemical nature of their surface by presenting soluble impurities to the atmosphere. Suspended ice particles are ubiquitous in the atmosphere at high latitudes and are responsible for halos, ice pillars, and other well-known optical phenomena (Tape, 2006). The ubiquity of ice, both as suspended particles and in snowpack, may indicate that cold plumes are "self-scrubbing" of nitrogen oxides through an $\mathrm{N}_{2} \mathrm{O}_{5}$ heterogeneous hydrolysis pathway that uses ice as the reactive surface. Dentener and Crutzen (1993) found that in order to reproduce $\mathrm{NO}_{\mathrm{x}}$ and nitrate ion deposition patterns observed at high latitudes, their model required inclusion of $\mathrm{N}_{2} \mathrm{O}_{5}$ heterogeneous hydrolysis on aerosol surfaces. While the $\gamma\left(\mathrm{N}_{2} \mathrm{O}_{5}\right)=0.1$ value used in their model was based on the literature available at the time, that value is higher than what was found in the recent literature and suggests other potential $\mathrm{N}_{2} \mathrm{O}_{5}$ loss mechanisms may be acting. Therefore, our finding that ice catalyzes $\mathrm{N}_{2} \mathrm{O}_{5}$ loss helps to resolve this modeling study with recent laboratory and mid-latitude field measurements. Further characterization of polluted ice as a sink for $\mathrm{N}_{2} \mathrm{O}_{5}$ is critical to understanding $\mathrm{NO}_{\mathrm{x}}$ budgets at high latitudes. Lastly, characterizing $\mathrm{N}_{2} \mathrm{O}_{5}$ loss on ice surfaces is important for determining the spatial and temporal footprint of acid deposition and nitrogen fertilization in such sensitive regions as the Arctic. As $\mathrm{NO}_{\mathrm{x}}$ inputs to the Arctic grow from increasing fossil fuel consumption or ship traffic in the Northwest Passage, the ecological impacts of $\mathrm{NO}_{\mathrm{x}}$ oxidation and the subsequent nitrogen deposition becomes more important to understand.

Acknowledgements. The authors would like to thank the following people for their assistance: Glenn Shaw, Catherine Cahill, and Alex Laskin for use of aerosol collection instruments; Thomas Douglas, Matthew Sturm, and Art Galvin for access to the meteorological tower and portable field hut; Laura Alvarez-Aviles for aiding in the ion chromatographic analysis; Eric Dick for access to the $\mathrm{NO}_{\mathrm{x}}$ instrument; and Paul Quist for use of his farm as a field site. Without the generosity of these people, this study would not have been possible. We thank Joel Thornton and Deanna Donohoue for informative discussions. This work was funded by the NSF under grant ATM-0 624448.

Edited by: J. Thornton

\section{References}

Allan, B. J., Carslaw, N., Coe, H., Burgess, R. A., and Plane, J. M. C.: Observations of the Nitrate Radical in the Marine Boundary Layer, J. Atmos. Chem., 33, 129-154, 1999.

Andersen, H. V. and Hovmand, M. F.: Ammonia and nitric acid dry deposition and throughfall, Water Air Soil Poll., 85, 2211-2216, 1995.

Andreas, E. L., Guest, P. S., Persson, P. O. G., Fairall, C. W., Horts, T. W., Moritz, R. E., and Semmer, S. R.: Near-surface water vapor over polar sea ice is always near ice saturation, J. Geophys Res., 107, SHE 8-1, doi:10.1029/2000JC000411, 2002.

Apodaca, R. L.: Nocturnal processing of nitrogen oxide pollution at high latitudes: off-axis cavity ring-down spectroscopy method development and field measurement results, Ph.D. thesis, University of Alaska Fairbanks, 116 pp., August 2008.

Apodaca, R. L., Simpson, W. R., Brauers, T., Brown, S. S., Cohen, R. C., Crowley, J., Dorn, H. P., Dubé, W. P., Fry, J., Fuchs, H., Haseler, R., Heitmann, U., Kato, S., Kajii, Y., Kiendler-Scharr, A., Labazan, I., Matsumoto, J., Nishida, S., Tillmann, R., Rohrer, F., Rollings A. W., Schlosser, E., Schuster, G., Tillmann, R., Villena, G., Wahner, A., Wegener, R., and Wooldridge, P. J.: Intercomparison of $\mathrm{N}_{2} \mathrm{O}_{5}$ sensors using SAPHIR reaction chamber, Atmos. Chem. Phys. Discuss., in preparation, 2008.

Ayers, J. D. and Simpson, W. R.: Measurements of $\mathrm{N}_{2} \mathrm{O}_{5}$ near Fairbanks, Alaska, J. Geophys. Res., 111, D14309, doi:10.1029/2006JD007070, 2006.

Ayers, J. D., Apodaca, R. L., Simpson, W. R., and Baer, D. S.: Offaxis cavity ringdown spectroscopy: application to atmospheric nitrate radical detection, Appl. Optics, 44, 7239-7242, 2005.

Benson, C. S.: Ice Fog: Low temperature air pollution, Tech. rep., Geophys. Inst. Rept. UAG R-173, Univ. of Alaska, 1965.

Bergholm, J., Berggren, D., and Alavi, G.: Soil acidification induced by ammonium sulphate addition in a Norway spruce forest in Southwest Sweden, Water Air Soil Poll., 148, 87-109, 2003. 
Brown, S. S., Stark, H., Ciciora, S. J., and Ravishankara, A. R.: Insitu measurement of atmospheric $\mathrm{NO}_{3}$ and $\mathrm{N}_{2} \mathrm{O}_{5}$ via cavity ringdown spectroscopy, Geophys. Res. Lett., 28, 3227-3230, 2001.

Brown, S. S., Stark, H., Ciciora, S. J., McLaughlin, R. J., and Ravishankara, A. R.: Simultaneous in-situ detection of atmospheric $\mathrm{NO}_{3}$ and $\mathrm{N}_{2} \mathrm{O}_{5}$ via cavity ring-down spectroscopy, Rev. Sci. Inst., 73, 3291-3301, 2002.

Brown, S. S., Stark, H., and Ravishankara, A. R.: Applicability of the steady state approximation to the interpretation of atmospheric observations of $\mathrm{NO}_{3}$ and $\mathrm{N}_{2} \mathrm{O}_{5}$, J. Geophys. Res., 108, 4539, doi:10.1029/2003JD003407, 2003.

Brown, S. S., Neuman, J. A., Ryerson, T. B., Trainer, M., Dube, W. P., Holloway, J. S., Warneke, C., de Gouw, J. A., Donnelly, S. G., Atlas, E., Matthew, B., Middlebrook, A. M., Peltier, R., Weber, R. J., Stohl, A., Meagher, J. F., Fehsenfeld, F. C., and Ravishankara, A. R.: Nocturnal odd-oxygen budget and its implications for ozone loss in the lower troposphere, Geophys. Res. Lett., 33(8), L08801, doi:10.1029/2006GL025900, 2006 a.

Brown, S. S., Ryerson, T. B., Wollny, A. G., Brock, C. A., Peltier, R., Sullivan, A. P., Weber, R. J., Dubé, W. P., Trainer, M., Meagher, J. F., Fehsenfeld, F. C., and Ravishankara, A. R.: Variability in nocturnal nitrogen oxide processing and its role in regional air quality, Science, 311, 67-70, 2006b.

Cahill, C. F.: Asian Aerosol Transport to Alaska during ACE-Asia, J. Geophys. Res., 108, 8664, doi:10.1029/2002JD003271, 2003.

Chapin, F. S.: Bonanza Creek Experimental Forest: Hourly Relative Humidity (mean, min, $\max$ ) at $50 \mathrm{~cm}$ and $150 \mathrm{~cm}$ from 1988 to Present, Bonanza Creek LTER Database, BNZD, NSF awards DEB-0620 579, DEB-0423 442, DEB-0080 609, DEB-9810 217 , DEB-9211 769, DEB-8702629 and USDA Forest Service, Pacific Northwest Research Station RJVA-PNW-01-JV-11261 952231, 241 pp., available at: http://www.lter.uaf.edu/data_detail. cfm?datafile_pkey=241, 2007.

Curry, J. A., Meyer, F. G., Radke, L. F., Brock, C. A., and Ebert, E. E.: The occurrence and characteristics of lower tropospheric ice crystals in the Arctic, Int. J. Climatol., 10, 749-764, 1990.

Dentener, F. and Crutzen, P. J.: Reaction of $\mathrm{N}_{2} \mathrm{O}_{5}$ on Tropospheric Aerosols: Impact on the Global Distributions of $\mathrm{NO}_{\mathrm{x}}, \mathrm{O}_{3}, \mathrm{OH}$, J. Geophys. Res., 98, 7149-7163, 1993.

Di Genova, F. and Dulla, R.: Studies and Data Relevant to $\mathrm{PM}_{2.5}$ Emissions In and Around Fairbanks, report to the Department of Environmental Conservation, Fairbanks, Alaska, 21 pp., 2007.

Fenn, M. E., Baron, J. S., Allen, E. B., Rueth, H. M., Nydick, K. R., Geiser, L., Bowman, W. D., Sickman, J. O., Meixner, T., Johnson, D. W., and Neitlich, P.: Ecological effects of nitrogen deposition in the western United States, Bioscience, 53, 404-420, 2003.

Finlayson-Pitts, B. J. and Pitts Jr., J. N.: Chemistry of the Upper and Lower Atmosphere, San Diego, Academic Press, 269 pp., 2000.

Geyer, A. and Stutz, J.: Vertical profiles of $\mathrm{NO}_{3}, \mathrm{~N}_{2} \mathrm{O}_{5}, \mathrm{O}_{3}$, and $\mathrm{NO}_{\mathrm{x}}$ in the nocturnal boundary layer: 2. Model studies on the altitude dependence of composition and chemistry, J. Geophys. Res., 109, D12307, doi:10.1029/2003JD004211, 2004.

Girard, E., Blanchet, J.-P., and Dubois, Y.: Effects of arctic sulphuric acid aerosols on wintertime low-level atmospheric ice crystals, Alert Nunavut., Atmos. Res., 73, 131-148, 2005.

Gotaas, Y. and Benson, C. S.: The effect of Suspended Ice Crystals on Radiative Cooling, J. Appl. Meteor., 4, 446-453, 1965.

Hallquist, M., Stewart, D. J., Baker, J., and Cox, R. A.: Hydrolysis of $\mathrm{N}_{2} \mathrm{O}_{5}$ on submicron sulfuric acid aerosols, J. Phys. Chem. A, 104, 3984-3990, 2000.

Hallquist, M., Stewart, D. J., Stephenson, S. K., and Cox, R. A.: Hydrolysis of $\mathrm{N}_{2} \mathrm{O}_{5}$ on submicron sulfate aerosols, Phys. Chem. Chem. Phys., 5, 3453-3463, 2003.

Hanson, D. R. and Ravishankara, A. R.: The reaction probabilities of $\mathrm{ClONO}_{2}$ and $\mathrm{N}_{2} \mathrm{O}_{5}$ on polar stratospheric cloud materials, J. Geophys. Res., 96, 5081-5090, 1991.

Heintz, F., Platt, U., Flentje, H., and Dubois, R.: Long-term observations of nitrate radicals as the Tor station, Kap Arkona (Ruegen), J. Geophys. Res., 101, 22 891-22 910, 1996.

King, M. D., Dick, E. M., and Simpson, W. R.: A new method for the atmospheric detection of the nitrate radical $\left(\mathrm{NO}_{3}\right)$, Atmos. Environ., 34, 685-688, 2000.

Koponen, H. T., Duran, C. E., Maljanen, M., Hytonen, J., and Martikainen, P. J.: Temperature responses of $\mathrm{NO}$ and $\mathrm{N}_{2} \mathrm{O}$ emissions from boreal organic soil, Soil Biol. Biochem., 38(7), 1779-1787, 2006

Leu, M. T.: Laboratory studies of interaction between trace gases and sulphuric acid or sulphate aerosols using flow-tube reactors, Int. Rev. Phys. Chem., 22, 341-376, 2003.

Levy II, H. and Moxim, W. J.: Simulated global distribution and deposition of reactive nitrogen emitted by fossil fuel combustion, Tellus B, 41, 256-271, 1989.

Mentel, T. F., Sohn, M., and Wahner, A.: Nitrate effect in the heterogeneous hydrolysis of dinitrogen pentoxide on aqueous aerosols, Phys. Chem. Chem. Phys., 1, 5451-5457, 1999.

Nakayama, T., Ide, T., Taketani, F., Kawai, M., Takahashi, K., and Matsumi, Y.: Nighttime measurements of ambient $\mathrm{N}_{2} \mathrm{O}_{5}, \mathrm{NO}_{2}$, $\mathrm{NO}$ and $\mathrm{O}_{3}$ in a sub-urban area, Toyokawa, Japan, Atmos. Environ., 42, 1995-2006, 2008.

Ohtake, T. and Huffman, P.: Visual Range in Ice Fog, J. Appl. Meteor., 8, 499-501, 1969.

Ohtake, T., Jayaweera, K., and Sakurai, K.: Observation of Ice Crystal Formation in Lower Arctic Atmosphere, J. Atmos. Sci, 39, 2898-2904, 1982.

Perry, K. D., Cahill, T. A., Schnell, R. C., and Harris, J. M.: Long-range transport of anthropogenic aerosols to the National Oceanic and Atmospheric Administration baseline station at Mauna Loa Observatory, Hawaii, J. Geophys. Res., 104, 18 52118 533, 1999.

Platt, U., Perner, D., Harris, G. W., Winer, A. M., and Pitts, J. N.: Detection of $\mathrm{NO}_{3}$ in the polluted troposphere by differential optical absorption, Geophys. Res. Lett, 7, 89-92, 1980.

Rosenfeld, D.: Suppression of Rain and Snow by Urban and Industrial Air Pollution, Science, 287, 1793-1796, 2000.

Sander, S. P., Friedl, R. R., Golden, D. M., Kurylo, M. J., Moortgat, G. K., Keller-Rudek, H., Wine, P. H., Ravishankara, A. R., Kolb, C. E., Molina, M. J., Finlayson-Pitts, B. J., Huie, R. E., and Orkin, V. L.: Chemical kinetics and photochemical data for use in atmospheric studies, Tech. rep., JPL Publication 06-2, 2006.

Seinfeld, J. H. and Pandis, S. N.: Atmospheric Chemistry and Physics, John Wiley \& Sons, New York, Chichester, Weinheim, 408-447, 1998.

Simpson, W. R.: Continuous wave cavity ring-down spectroscopy applied to in situ detection of dinitrogen pentoxide $\left(\mathrm{N}_{2} \mathrm{O}_{5}\right)$, Rev Sci. Instrum., 3443-3452, 2003.

Stutz, J. B., Ackermann, R., Geyer, A., White, A., and Williams, E.: Vertical profiles of $\mathrm{NO}_{3}, \mathrm{~N}_{2} \mathrm{O}_{5}, \mathrm{O}_{3}$, and $\mathrm{NO}_{\mathrm{x}}$ in the 
nocturnal boundary layer: 1. Observations during the Texas Air Quality Study 2000, J. Geophys. Res., 109, D12306, doi:10.1029/2003JD004209, 2004.

Tape, W.: Atmospheric Halos and the Search for Angle X, American Geophysical Union, 238 pp., 2006.

Toon, O. B.: How pollution suppresses rain, Science, 5459, 17631765, doi:10.1126/science.287.5459.1763, 2000.

Twomey, S.: Pollution and the planetary albedo, Atmos. Environ., 8, 1251-1256, 1974.
Witte, H. J.: Airborne observations of cloud particles and infrared flux density $(8-14 \mu \mathrm{m})$ in the Arctic, Master's thesis, University of Washington, 102 pp., 1968.

Wood, E. C., Wooldridge, P. J., Freese, J. H., Albrecht, T., and Cohen, R. C.: Prototype for in situ detection of atmospheric $\mathrm{NO}_{3}$ and $\mathrm{N}_{2} \mathrm{O}_{5}$ via laser-induced fluorescence, Environ. Sci. Technol., 37, 5732-5738, 2003. 